\title{
Učenje za družino
}

Nives Ličen

\section{Družina je osnovna institucija zasebnega življenja, kjer se oblikuje za ljudi večina pomembnih razmerij. Je socialna skupina, v katero smo stalno in dolgotrajno vključeni.}

$\mathrm{Na}$ življenje lahko gledamo kot na vrsto stopenj; skozi nekatere človek mora iti, skozi druge pa lahko gre, če se tako odloči. Deloma je taka faza tudi družinsko življenje, ki poteka v dveh delih: otroci se rodijo (ne po lastni volji) v družino svojih staršev, v njej odraščajo, odrastejo, nazadnje pa sami prevzamejo vlogo staršev in zakoncev v novi družini. Včasih poskrbijo tudi za ostarele starše, tako da nastane razširjena družina. Noben odrasel clovek ni prisiljen živeti v družinski zvezi. Če to počne, »družinske zadeve« vključi med svoje vrednote.

Družina, v kateri po navedbah posameznih avtorjev preživimo dve tretjini ali tri četrtine časa, v sodobni družbi služi za zadovoljevanje osnovnih življenjskih potreb, ima socializacijsko vlogo in zagotavlja psihološko varstvo svojim članom, je »pristanišče«; njene funkcije pa se nanašajo na:

- biološko reprodukcijo,

- zadovoljevanje čustvenih potreb,

- skrb za otroke in vzgojo otrok,

- skrb za dom, kjer poteka zadovoljevanje osnovnih potreb kot so hranjenje, fizična in socialna varnost,

- prenašanje kulturnih vzorcev in izročila, znanja iz roda v rod.

Družino sestavljajo posamezniki, ki sprejemajo različne vloge - vlogo partnerja, starša, otroka. Vendar pa družina ni le vsota teh posameznikov, temvec je uglašen sistem. Tudi družinsko življenje ni vsota dogodkov, marveč proces.

Zato naj bi bil dom takšno okolje, ki omogoča, da se ob medsebojni povezanosti članov družine razvijejo in ohranjajo razlike, in sicer tako, da so se le-ti pripravljeni spopadati s problemi drugega in jih reševati.

Vsaka družina je izvirna in posebna konstrukcija, vsaka zase mora najti svojo lastno homeostatično formulo in jo vedno znova prenavljati glede na spremembe, ki se dogajajo v njenem razvoju. Da bi takšno ravnotežnostno formulo ustvarili, pa potrebujemo veliko znanja, drugačnega od tistega, s katerim smo se usposobili za poklicno delo. Partnerstvo je namreč v sodobnih razmerah malo povezano $\mathrm{z}$ delom in tistimi spretnostmi, $\mathrm{s}$ katerimi smo uspešni na delovnem mestu.

Mogoče bo partnerstvo bolj povezano $\mathrm{z}$ delom, če se bodo uresničile domneve A. Tofflerja (1983), da se bo družina iz sedanje porabniške enote $\mathrm{v}$ prihodnosti spremenila $\mathrm{v}$ proizvodno enoto, ki bo imela svoj sedez $\mathrm{v}$ »elektronskih hisicah«. To bo spremenilo razmerja v družinah, saj bodo otroci v stiku s starši in njihovim delom od mladih nog, pojav "neskoncno podaljšane adolescence se bo izgubil, ker bodo tudi otroci imeli produktivno vlogo. Partnerja bosta skupaj tudi v delovnem procesu, kar bo verjetno po svoje vplivalo tudi na izbiro partnerja.

(Tako je v Veliki Britaniji že zdaj zaposlenih 1.200.000 ljudi doma pri računalniku. V matičnih podjetjih se srečujejo le enkrat na teden, ko usklajujejo delo in skupaj načrtujejo. Vir: TV-oddaja Made in Slovenija v februarju 1995.)
Za zdaj pa družinsko življenje od nas zahteva, da razvijamo tudi druge sposobnosti, si pridobimo drugačno znanje, kot ga potrebujemo za svojo poklicno pot.

Za dobro partnersko razmerje se moramo nauciti spoznavati drugega človeka, t.j. partnerja, kot posameznika $\mathrm{z}$ njegovimi posebnimi lastnostmi. Spoznati ga moramo tudi kot predstavnika drugega spola. $\mathrm{Za}$ dober odnos je potrebno veliko priprav in truda, če hočemo biti uspešni. In vendar je to še vedno dokaj prepuščno improvizaciji in naključjem! Naučiti se moramo gledati na partnerstvo kot na proces, $v$ katerega lahko vlagamo, ga poganjamo dalje ali pa pustimo, da usahne.

Raziskava uspešnih zakonov je pokazala, da sta partnerja drug drugemu učitelja. Načelo takega vzajemnega izobraževanja je vzajemna pozornost in obojestransko zanimanje za različne pojave, v katere se partnerja vključujeta (Lengrand, 1976, str. 53).

Tudi za razmerja med starši in otroki lahko rečemo, da so največkrat dokaj prepuščna »naravi«. Sami sebe prepričujemo, da je dovolj, da imamo otroka radi, in bomo že ravnali tako, da bo za otroka najboljŁe. Toda: »Ljubezen ni dovolj! « je zapisal Bettelheim (1976).

Družinska vzgoja je bila nekoč za starše lažja naloga. Z raziskavami plemenskih skupnosti so socialni antropologi ugotovili, da le-te ne poznajo težav pri vzgoji, ker je kultura plemenskih skupnosti takšna, da jo lahko osvoji otrok do osmega leta starosti. Prevladuje namreč kultura, ki je delovno nazorna, delo se prepleta s socialnimi doživetji, razmerja med ljudmi so jasna, zato je mogoč učinkovit socialni nadzor.

Dokaj preprosta je bila tudi družinska vzgoja v Evropi v obdobju, ki je temeljilo na poljedelstvu. Tedaj sta okolje in družina socializirala otroka tako, da sta ga postopno vpeljevala $\mathrm{v}$ delo.

Zasuk od konkretne delovne kulture $\mathrm{k}$ abstraktno tehnični so pospremile tehnične novosti in razvoj naravoslovja; novih spoz* nanj so se otroci naučli $v$ šoli. Krhati se je začela avtoriteta staršev, družinsko vzgojo so začele obremenjevati tegobe pubertete, saj mladi s telesno zrelostjo niso dosegli tudi socialne zrelosti (Bergant, 1981).

Težave družinske vzgoje povečujejo zanimanje za teorijo družinske vzgoje, ki naj bi pomagala staršem.

Vprašanje, ki spremlja življenje staršev, je vedno enako: „Bom ravnal(a) pravilno? Sem zares sposoben(a), da svojemu otroku pomagam odrasti $\mathrm{v}$ razumevajoč, umirjeno in uravnoteženo osebnost? « Odgovora nam na žalost ne more dati nihče. Samo čas nam bo pokazal, ali je bilo naše ravnanje pri opravljanju poklica matere in očeta pravilno. To pa seveda še ne pomeni, da ni treba poslušati nasvetov, iskati po knjigah, spraševati izkušenih. Nasprotno: prav zato, ker ni nikakršnega priročnika, s katerim bi se hitro usposobili za poklic matere in očeta, in moramo za vsakega otroka poscbej iskati poti in rešitve, potrebujemo veliko znanja. 


\section{Model življenjskega ciklusa družine}

1. Doba oblikovanja družine (zakonca brez otrok)

2. Razširjanje družine (zgodnje starševstvo)

3. Osnovnošolsko obdobje otrok

(prvi otrok od 6. do 13. leta)

4. Mladostniško obdobje otrok

(prvi otrok od 14. do 19. leta)

5. Postadolescentsko obdobje otrok

(od 20. leta do odhoda prvega otroka iz družine)

6. Začetek zoževanja družine

(odhajanje otrok iz družine, začetek »praznjenja gnezda«)

7. Zožana družina

(»prazno gnezdo«, vračanje pomena partnerskemu razmerju)

8. Ovdovelost (smrt enega od partnerjev, otroci počasi postajajo »starši« svojih staršev)

Iz prikaza družinskega cikla je razvidno, kako je družinski sistem odvisen od sprememb. Naloga družine je, da dovoljuje spremembe in hkrati ohranja kontinuiteto. Naloga ni lahka, ker spremembe niso gladke, nezaznavne. Vsak korak, ki ga naredi član družine na poti razvoja, spremeni sestavo družine. Člani družine se prilagajajo in vedno znova skušajo vzpostaviti ravnotežje. Iz tega pregleda je še posebej vidno, kako se mora družina prilagajati odraščnju otrok, njihovim potrebam. Skladno s tem se morajo spreminjati tudi dejavnosti staršev. Družina se mora prilagajati na fizično, kognitivno in tudi filozofsko spreminjanje posameznika. Ko stare rešitve ne delujejo več, je družina »zamaknjena« in potrebuje nove rešitve. Te pa vedno ne ustrezajo vsem članom družine. Družina ni ohlapna skupina povezanih ljudi različne starosti, temveč je socialni sistem, ki je do danes ostal nenadomestljiv.

Prav gotovo je družina lahko vir veselja ali žalosti. Če hočemo, da je družina vir veselja, mora biti trdna, vloge članov morajo biti usklajene in le-ti morajo biti pripravljeni vedno znova usklajevati svoje družinske naloge z nalogami drugih družinskih članov. Družina se mora učiti »držatí skupaj«, ne le v veselju, temveč tudi v trpljenju, kar pomeni, da se deleži posameznikov spreminjajo.

Oče ali mati sta včasih zaradi tekme za uspeh, boja za kariero, $v$ družini malo navzoča, zato mora njun prostor zapolniti nekdo drug ali pa ostane praznina. V jedrnih družinah je to težje kot $v$ razširjenih, kjer lahko dedek prevzame del očetove vloge, babica del materine.

Na vsaki stopnji se družina srečuje $z$ drugačnimi težavami. Ko se družina osnuje, začne razvijati svoj družinski slog, pripravlja se na rojstvo prvega otroka, ki družinsko ozračje pa tudi vloge družinskih članov bistveno spremeni, saj moški in ženska, ki sta bila do tedaj v vlogi zakoncev, sprejmeta tudi vlogi očeta in matere. Ti se bosta spreminjali, ostali pa bosta trajni. Tudi potem, ko se bodo otroci osamosvojili, odselili, bosta starša še vedno nosilca materinske in očetovske vloge, le da se bosta bistveno spremenili. Prehod v starševstvo pomeni prilagajanje nemočnemu otroku. Š posebno prvi mesec po rojstvu je naporen za mater. Ugotavljajo, da je očetovo vedenje v zvezi s starševstvom pomembnejše, kot so mislili. Med drugim je pomembno že očetovo vedenje $\mathrm{v}$ ženini nosečnosti, ki močno vpliva na kasnejše splošno starševsko vedenje partnerjev (Mercer, 1986; Morris, 1988, po L'Abate, 1994).

Ko zadnji otrok zapusti »gnezdo«, se partnerja znajdeta sama, razviti morata spet svoj slog življenja, ki ni več tako močno označen $\mathrm{z}$ otroki.
Fleksibilnost (prilagodljivost) je ključ za uspešne spremembe $v$ družini pa tudi pri posamezniku. Vsaka sprememba povzroča stres, kajti prilagajanje na spreminjajoče se okolje, bodisi $\mathrm{v}$ dobrem ali v slabem, ni preprosto.

\begin{tabular}{lr}
\hline Sprenemba & Tocke \\
\hline smrt zakonca & 100 \\
\hline razveza & 73 \\
\hline poroka & 50 \\
\hline nosečnost & 40 \\
\hline težave v spolnosti & 39 \\
\hline prihod novega družinskega ̌lana & 39 \\
\hline spremenjeno število zakonskih prepirov & 35 \\
\hline otrok zapusti dom & 29 \\
\hline težave s sorodniki & 29 \\
\hline izjemen osebni uspeh & 28 \\
\hline začetek/konec šolanja & 25 \\
\hline sprememba življenjskih navad & 24 \\
\hline sprememba bivališča & 20 \\
\hline
\end{tabular}

(Vir: Holmes in Rachey, 1967; po Skynner 1994, str. 64)

Fleksibilna menjava, nekakšen podarim-dobim, je nujna tudi med podskupinami družine (npr. otroci-starši). Učenje poteka tudi v družini. Ne le otroci od staršev, tudi starši se učimo od otrok. Medgeneracijsko učenje poteka v obe smeri.

Največje spremembe povzroča prihajanje in odhajanje družinskih članov. Začetek odhajanja je obdobje, ko začne pubertetnik iskati alternative in skuša utrditi svojo identiteto.

Individualizacija poteka $v$ skupini in je odvisna od sposobnosm ti posameznika biti ločen od skupine in hkrati povezan $\mathrm{z}$ njo. Raziskava, ki jo omenja Cooper (1986) (po L'Abate, 1994), kaže, da so imeli adolescenti, ki so osamosvajanje najlažje prešli, take starše: zaupljive, dosledne (besede in dejanja so bili usklajeni), ločevali so med svojimi potrebami in potrebami svojih otrok, poskrbeli so za priložnosti, da so adolescenti lahko razvijali svojo samostojnost v varnem okolju (npr.: počitniške zaposlitve, obšolske dejavnosti).

Močnejšo spremembo doživi človek v obdobju staranja. Mlajకi gredo svojo pot, starši se upokojijo, starajo se, umirajo. Vedno znova je treba redefinirati članstvo družine, podskupine, stike med njimi in stike med novimi družinami.

\section{Spremembe znotraj družinskega cikla}

Prikazani družinski življenjski krog je seveda le eden od mnogih, saj ni nujno, da bo določena zakonska zveza trajna. Upoštevati moramo tudi, da je tradicionalna družina $\mathrm{z}$ dvema staršema in po možnosti dvema otrokoma le ena od množice družinskih oblik. Poznamo tudi enoroditeljsko družino, dopolnjeno družino, razširjeno družino...

Spremembe pa se dogajajo tudi znotraj družinskega cikla. Nekatere stopnje se časovno podaljšujejo, druge se skrajšujejo, pojavljajo pa se tudi nove faze (npr. partnerja vzpostavljata novo zvezo). Vnovično sklepanje zakonskih zvez ustvarja skupine, katerih člani so tudi otroci iz prejšnjih zakonov. Nekaj strpnega humorja rabimo, da rešimo takle telefonski klic: »Halo, tukaj žena prejšnjega moža žene vašega bivšega moža. Kličem, da bi vam povedala, da je ravnokar klicala žena vašega bivšega moža in me je prosila, naj vam sporočim, da bo pripeljala otroke domov v soboto, « $\mathrm{Za} \mathrm{to}$, da živimo v medsebojnih odnosih, ki jih prikazuje, moramo biti zelo prilagodljivi.

Težko je postavljati casovne meje, saj jo cas med rojstvom prvega in zadnjega otroka vse daljši. Težko je tudi reči, kdaj otro- 
ci zapuščajo družino, saj je to odvisno od mnogih družbenih, ekonomskih in custvenih dejavnikov.

Podatki kažejo, da se je povprečna starost matere ob rojstvu prvega otroka povečala, in sicer z 22,7 leta $v$ letu 1976 na 24,2 leta v letu 1992. Ker se tudi življenjska doba ljudi daljša, lahko rečemo, da se zlasti podaljšuje obdobje, ko je družina brez otrok, bodisi pred rojstvom otrok ali po odhodu otrok od doma.

Družinsko okolje, ki omogoča rast posamezniku, je tako, da so strukture in hierarhija družinskih podskupin jasne, pa vendar prilagodljive in omogočajo ustrezno komunikacijo.

Razlike med člani so sprejete, vsak posameznik ima tudi svoja področja delovanja, ki niso skupna z drugimi. Custva so v taki družini razvejana, tako da ni vedno izraženo le eno (npr. jeza). Za dinamiko razmerij je pomembno, da se člani odzivajo na ljudi v sedanjosti in ne ciljajo na preteklost ali prihodnost.

\section{Kakšno znanje bi połrebovali?}

Družinsko življenje zahteva od nas občutek za sodelovanje z drugimi ljudmi pa tudi zalogo spretnosti in informacij, da znamo v nastalih položajih prav ravnati. Potrebovali bi predvsem izobraževanje za kvalitetnejše bivanje posameznika, za skupni čas, ki ga preživijo člani v družini, predvsem za prosti čas, in za vloge, ki jih imamo oziroma jih bomo sprejemali $v$ družini. Posebno področje je še izobraževanje družin s posebnimi potrebami, kot so rejniki, posvojitelji, družine $\mathrm{z}$ invalidnimi otroki, $\mathrm{z}$ odvisniki...

\section{Partnerska vloga}

Temelj družinskega življenja je razmerje med zakoncema. Tako kot razmerja med rodovi so se spremenila tudi razmerja med spoloma. Nekoč je veljalo, da ima mož ženo v posesti. Prav v zvezi s tem je bil znan običaj v Benetkah. Dož je vrgel v morje zlat prstan in rekel: "Morje, poročamo se s tabo v znamenje svobodnega gospodovanja nad tabo.«

Partnerstvo dandanes ne vsebuje (naj ne bi vsebovalo) posedovanja.

V vsakem partnerskem razmerju morajo imeti člani možnost, da rešujejo razlike $v$ mišljenju. Raziskave ugotavljajo, da sloni sposobnost pogajanja v zakonu na izkušnjah v pogajanjih.

Pogajanje, »kreganje«, je med zakoncema drugačno kot $\mathrm{v}$ siceršnjih partnerskih odnosih, saj se dogaja v kontekstu intimnosti in odpuščanja. Močan čustveni dejavnik, ki pri tem deluje, je lahko konstruktiven ali pa destruktiven. Ljubezen se lahko prelevi v sovraštvo. Č se tega zavedamo, če imamo potrebno znanje in spretnost, se lahko izognemo »korakom v prazno «. Ko se težava pojavi, se znamo orientirati, jo znamo vsaj približno definirati in če si ne znamo pomagati, poiščemo pomoč.

Pesnik Byron je zapisal, da je lažje umreti za žensko, ki jo ljubimo, kot pa z njo živeti. $S$ tem je prikazal staro resnico o zakonu, ki postane včasih za mlade ljudi, polne lepih upov, vir neznosnil razočaranj. Namesto neskoncne sreče doživljajo neskončen dolgčas, ki ga prekinjajo prepiri.

Vzrok za takšno razhajanje med pricakovanji in resničnostjo lahko iščemo v nerealnih pričakovanjih, problematiki zvestobe in ljubosumja, spolnosti, zakonskih prepirih (Zvonarević, 1981, str. $572)$.

Najveçje nerealno pričakovanje mladih je, da v zakonu ne bo prepirov. Prepiri nastanejo zaradi razlixnih vzrokov (razlicne navade zakoncev, negiranje individualnosti, ljubezenske oscila- cije, divergenten razvoj po poroki). Že preden se začno prepiri, si moramo privzgojiti sposobnost sprejemanja kompromisov, naučiti se moramo pogajati $z$ drugim, komunicirati v takih situacijah,

Naloge, ki jih v zvezi z domom in družinskim okoljem pripisujemo vlogi partnerja in starša, so še skrbniške in finančne. Tudi tu potrebujemo določeno znanje, da bomo uspešni.

Skrbeti moramo za tisto, kar zagotavlja fizično in gmotno blaginjo doma (kuhanje, pospravljanje, čiščenje, nakupovanje...).

\begin{tabular}{|c|c|c|c|}
\hline \multirow[t]{2}{*}{ Gospodinjska opravila } & \multicolumn{3}{|c|}{ Vecinoma opravljajo } \\
\hline & moski & Zenske & oba \\
\hline pranje & 1,8 & 95,7 & 2,5 \\
\hline sivanje, likanje & 1,3 & 97,7 & 1,0 \\
\hline kuhanje & 2,2 & 90,4 & 7,3 \\
\hline ciščenje stanovanja & 5,6 & 83,2 & 11,2 \\
\hline nakupi & 18,7 & 64,2 & 17,1 \\
\hline pomivanje posode & 4,1 & 89,0 & 6,9 \\
\hline skrb za denarne zadeve & 29,9 & 34,3 & 35,8 \\
\hline drobna popravila & 86,4 & 9,6 & 4,0 \\
\hline \multicolumn{4}{|l|}{ Ukvarjanje $z$ otroki? } \\
\hline nega otrok & 2,8 & 74,8 & 22,4 \\
\hline vzgoja & 5,4 & 54,2 & 40,4 \\
\hline pomoč pri šolskem delu & 13,8 & 61,0 & 25,2 \\
\hline
\end{tabular}

(Vir: Sociološki, demografski in medicinski vidiki nizke rodnosti $v$ Sloveniji, 1989, podatkovna baza; po Družine: različne-enakopravne, str. 73)

Največ teh opravil je na ramenih ženske, izjema so le manjša popravila in dename zadeve.

Oskrba družine je povezana $\mathrm{z}$ denarno platjo (dohodki, davki, posojila...). Tu se postavita dve vprašanji: koliko dohodkov ima družina in koliko porabi. Pomembnejše je seveda drugo vprašanje, ki se povezuje tudi s tem, kako družina porabi denar (alokacija denarja). To so pomembne naloge za fizično preživetje družine pa tudi za dobro počutje, zato je dobro vedeti, kako jih lahko najbolj učinkovito opravimo.

Danes je finančna plat, vsaj dohodkovna, večinoma stvar staršev oziroma partnerjev, v preteklosti pa je bilo drugače (pastirji, pestrne..., prim. A. Puhar: Prvotno besedilo življenja).

\section{Vloga staršev}

Kakšen je posameznik kot starš ali kot partner, je odvisno od mnogih osebnostnih značilnosti. Za obe vlogi pa je nujno dvoje: sposobnost ljubiti in sposobnost pogajati se (L'Abate, 1994, str. 117, 149),

Ljudje smo glede teh dveh vlog, ki sta tako pomembni v našem življenju, zelo kratkovidni. Domišljamo si, da se tega naučimo v svojem otroštvu, da nam je tako znanje kar vrojeno. Ker smo se učili od navadnih smrtnikov, ki delajo napake, ponavljamo te napake za njimi. Tu se pojavlja se problem, ko so starši prezaposleni in vzgajajo otroke stari starši, kar pomeni, da pride do preskoka generacije. Dejstvo je, da večina med nami, tudi tisti, ki smo poklicni pedagogi, nismo ši skozi trening za pripravo na starševstvo in partnerstvo. Torej se nismo pripravljali za dvoje temeljnih in najbolj zapletenih vlog v življenju.

Ko sprejmemo starševsko vlogo, nismo starši le svojim otrokom, temveč $v$ četrtem obdobju tudi svojim staršem, ki se v obdobju vnovične odvisnosti naslanjajo na svoje otroke.

In še drugi vidik: starševstvo se nadaljuje tudi v vlogi babic in 
dedkov. Ko postanemo stari starši, moramo vedeti, kako obdržati razdaljo »s skrbjo«. Naši otroci so zdaj starši, mi moramo opustiti to vlogo in sprejeti drugo, vlogo starih staršev, upokojencev, vdovcev.

Starševska vloga zahteva veliko več kot le fïnančno podporo otrokom, skrb za zdravje, hrano. V vsakem staršu se mora razviti vrednostni sistem, lestvica prioritet, ki priznavajo pomembnost otroka, da se zdijo vse žrtve smiselne.

Vlogi starša in partnerja sta povezani. Razmerje med možem in ženo ne bo nikoli več enako tistemu, ki sta ga imela, preden sta imela otroke. Tudi če otroci odrastejo, odidejo, starši ne nehajo biti starši.

Da sta človeka ucinkovita starša, morata imeti dobre medsebojne odnose. Biti morata pripravljena na skupno delo, z različnimi sposobnostmi igrati različne vloge s skupnim ciljem. Seksistični pomeni se pri takem delu večinoma izgubijo (Skynner, 1994).

Starši morajo biti samostojne osebnosti, da otroku pomagajo postati samostojna osebnost.

V zvezi s starševsko vlogo družinski terapevti opozarjajo:

a) otroci so obiskovalci, zato moramo skrbeti tudi zase in za svoj zakon,

b) ambivalentna čustva do otroka niso nic nenavadnega,

c) ozračje v družini se spreminja, vsak otrok je rojen in raste $v$ drugačnem ozračju,

c) za vzgojo otrok ni dovolj le ljubezen, potrebujemo tudi znanje,

d) z otroki naj bi uživali, ne pa trpeli.

\section{Sklep}

Podobe sodobne družine so različne. $\mathrm{Na}$ eni strani so tiste, $\mathrm{ki}$ so »varni pristani«, kjer »sem jaz tak, kakršen sem«, na drugi strani pa so đružine bojišča, področja egoizma in nasilja. Vmes je cela lestvica družinskih fotografij.

Spreminjanje družin se kaže v naslednjih potezah:

a) širi se paleta družinskih oblik in stilov (jedrne, razširjene, reorganizirane), zato govorimo o družinah, ne več o eni tipični družini,

b) zakonska zveza izgublja svoj status ( $v$ Franciji in Veliki Britaniji se 30 odstotkov otrok rodi zunaj zakonske zveze, v Sloveniji 26,4 odstotka, podatek za leto 1991),

c) Število razvez narǎ̌ča,

c) veča se število reorganiziranih in enoroditeljskih družin,

d) družinski cikli se spreminjajo.

Prebivalci Slovenije pripisujejo družini velik pomen, saj jo poleg poklicnega življenja štejejo med najpomembnejša področja svojega življenja. Za poklicno življenje se pripravljamo $\mathrm{z}$ dolgim solanjem, koliko pa se pripravljamo za družino?

Na najodgovomejšo nalogo in najdaljšo vlogo v življenju smo najmanj pripravljeni.

Pri rednem šolskem izobraževanju naj bi človek pridobil tudi tako znanje, ki pomaga izboljševati bivanje posameznika pri njegovi osebnostni rasti. Na primer vedenje o življenju v skupini, o prostem času, zabavi, reševanju sporov, medsebojnem sporazumevanju...

Tako znanje je podlaga za izobraževanje za starševsko in partnersko vlogo.
Skladno z razvojem družinskega cikla pa bodo odrasle zanimale se različne druge vsebine.

Ne slepimo se, da bomo $z$ izobraževanjem staršev obvladali vzgojno področje družine. Gre le za to, da pripomoremo k ozaveščnju, da postopoma izboljšujemo ravnanje. Tudi ne gre za malikovanje družine, ki naj daje vrle državljane in državljanke, gre za družino, $v$ kateri nas večina živi in želimo čim lepše preživeti. Tudi ne gre za dobre namene, $\mathrm{s}$ katerimi bo tlakovana pot v pekel, in ne za tako »skrb za družino, ki bi vključevala silo, nasilje do tistih, ki hočejo živeti drugače. Car izobraževanja je ravno $v$ tem, da lahko stvari sprejmeš ali zavmeš, zato ne smemo nobenega izobraževanja postaviti kot obvezno.

Izobraževanje za družino ne izhaja iz nezadovoljstva in nezaupanja do konkretnih ljudi in njihovih življenjskih stilov, marveč izhaja iz vprašanja, kako se da kljub različnosti bolje preživeti.

\section{Nives Ličen}

asistentka-stažistka na Filozofski fakulteti

\section{Lileratura}

AMIDEl, B. G. (1994): Come insegnare l'educazione ai vostri figli. Piemme, Casale Monferrato.

BERGANT, M. (1981): Družina - zakon - ljubezen na razpotjih. Zavod SRS za šolstvo, Ljubljana.

BETTELLHEIM, B. (1976): Pogovori z materami. Mladinska knjiga, Ljubljana.

BRAJS̆A, P. (1985): Se da živeti v dvoje? DE, Ljubljana.

ČAČINOVIČ-VOGRINČIČ, G. (1992); Psihodinamski procesi v družinski skupini, Advance, Ljubljana.

GORDON, T. (1989): Družinski pogovori. Svetovalni center za otroke, mladostrike in starše, Ljubljana.

L'ABATE, L. (1994): A Theory of Personality Development. John Wiley \& Sons, New York.

LENGRAND, P. (1976): Uvod u permanentno obrazovanje. BIGZ Beograd,

LUKAS, E. (1993): Družina in smisel. Mohorjeva družba, Celje,

PUHAR, A. (1982): Prvotno besedilo življenja. Globus, Zagreb,

Ljubljana.

RENER, T., V. POTOČNIK, V. KOZMIK (Ured.) (1995): Družine: razliðne - enakopravne. Vitrum, Liubljana.

SAVIFEVIC, D. (1973); Obrazovanje za život u porodici. Zavod za izdavanje udžbenika Srbije, Beograd.

SKYNNER, R., J. Cleese (1994): Družine in kako v njih preživeti. Tangram, Ljubljana.

TOFFLER, A. (1983): Trefi talas. Jugoslavija, Beograd.

TOURNIER, P. (1980): Više razumijevanja a braku. Oko tri ujutro, Zagreb.

ULE-NASTRAN, M. (1993): Psihologija vsakdanjega življenja. Znanstveno in publicistično središ̌̌e, Ljubljana.

ZVONAREVIĆ, M. (1981): Socijalna psihologija. Školska knjiga, Zagreb. 